Amao, O. \& Amaeshi, K. 2008, 'Galvanising Shareholder Activism: A Prerequisite for Effective Corporate Governance and Accountability in Nigeria', Journal of Business Ethics, vol. 82, no. 1, pp. 119-130.

\title{
Galvanising shareholder activism: a prerequisite for effective corporate governance and accountability in Nigeria
}

\section{Abstract}

Shareholder activism has been largely neglected in the few available studies on corporate governance in sub Saharan Africa. Following the recent challenges posed by the Cadbury Nigeria Plc, this paper examines shareholder activism in an evolving corporate governance institutional context and identifies strategic opportunities associated with shareholders' empowerment through changes in code of corporate governance and recent developments in information and communications technologies in Nigeria; especially in relation to corporate social responsibility in Nigeria. It is expected that the paper would contribute to the scarce literature on corporate governance and accountability in Africa.

Keywords: Business law; Corporate governance; Corporate accountability; Shareholder empowerment and activism; Nigeria 


\section{Introduction}

Publicly quoted companies in Nigeria are gradually - albeit very slowly attuning to principles of good corporate governance. In recognition, Nigeria was recently rated average in the World Bank investor protection index, which covers transparency of transactions, liability for self-dealing, shareholders ability to seek redress against officers and directors. ${ }^{1}$ However, the current Cadbury Nigeria Plc (a subsidiary of Cadbury Schweppes) financial accounting saga (see appendix for details) ushers in a new dawn in corporate governance and accountability in Nigeria which challenges shareholders' ability to hold management to account through activism - a way by which shareholders can influence a corporation's behaviour by exercising their rights as owners. ${ }^{2}$

Shareholder activism is not a new phenomenon in developed market economies. O'Rourke did an historical analysis of shareholders activism which dates back to some sixty years in the U.S. She noted the 1946 landmark requirement under US Securities and Exchange Commission (SEC) Rule, which requires companies to include shareholder resolutions in proxy statements. This has remained the rule till date. The 60's and 70's witnessed the use of shareholder proxy to pressure companies in more areas such as product safety, environmental pollution and employment discrimination. In the

\footnotetext{
${ }^{1}$ See http://www.doingbusiness.org "The indexes vary between 0 and 10, with higher values indicating greater disclosure, greater liability of directors, greater powers of shareholders to challenge the transaction, and better investor protection". Nigeria scored 5 on the scale while the OECD average is 6 ${ }^{2}$ It is instructive to note that the irregularities in the Cadbury case was discovered after the parent company, Cadbury Schweppes, increased its stake in the company from $46 \%$ to $50 \%$. This development questions the ability of shareholders in Nigeria to act effectively within the corporate governance framework in the country.
} 
80's shareholder activism shifted to anti takeover activities, which according to O'Rourke may partly be due to a swing away from public interest movement towards making companies more competitive. However, the call for social and environmental responsibility emerged again in the 1990's with increased involvement of shareholder activities. According to her, shareholder activist groups in the US include individual shareholders, Non governmental Organizations, Churches and religious groups, mutual and pension funds and other umbrella groups.

The aim of this paper is to explore how recent developments in Nigeria contribute to shareholders activism and how to improve participation of shareholders in corporate governance - the distribution of rights and responsibilities and responsibilities among different actors involved in the corporate organization (Aguilera and Jackson, 2003). The extant literature on corporate governance and accountability tends to take shareholder power and influence to enforce their rights as a given, and from this point of view often argue for stakeholder influence and empowerment, instead. This paper offers a contrary perspective wherein shareholders power and influence is not as powerful as often assumed and presented in the extant literature. A fair treatment of shareholders and their ability to have their voice heard is one of the major issues at the core of best corporate governance practice (McNeil, 2005). It is the position of this paper, therefore, that in order to increase participation in the financial market, in an economy such as Nigeria, it would be necessary to gain shareholders' confidence, by demonstrating that their 
companies are being run and managed efficiently, and that they have a real role to play in the company.

For the purpose of this paper, it would be necessary to make a distinction between universal share ownership and universal owners (Turnbull, 1993). According to Turnbull 'a "universal owner" is an institution which effectively owns a small portion of the economy', while universal share ownership presumes direct ownership by individual stakeholders. Universal ownership has two important drawbacks, which were identified by Turnbull. In the first place they may seek to maximize profits by externalizing social costs to taxpayers whom they represent. Secondly, it also raises the problem of the same owners being involved in the governance of competing firms. As noted by Maassen and Brown (2006), the composition of institutional (universal owners) investors varies widely and consequently affects their voting disposition. They further noted that while institutional shareholders are capable of influencing corporate behaviour, their effectiveness is widely debated in the literature. It was noted that institutional investors, such as mutual funds, have tended to align with management and have been passive while institutional investors, such as public pension schemes, appear to be more pro-active (Maassen and Brown, 2006:224). Studies have also found that there are weak links between institutional shareholding and firm performance, while the prospects of misdirection of shareholder activism also affect firm effectiveness (Maassen and Brown, 2006: 244/245). Universal share ownership, in the contrary, avoids the problems of universal owner by increasing participation of other stakeholders, such as employees, ensuring 
that same owners do not participate in the governing of competing firms and that institutional holding is not run in a way that transfers the costs of externalities to people who may be the shareholders they are representing (Turnbull, 1997). The shareholder activism advocated in this paper primarily relates to universal share ownership.

Following ongoing corporate governance reforms and recent developments in information and communication technologies in Nigeria, this paper examines the possible effects of these on shareholder democracy - by exploring the viability of mobilizing individual shareholders (i.e. universal share owners) in order to make them real actors in corporate governance and accountability in Nigeria. Aguilera and Cuervo -Cazurra (2004) suggested that there are at least two possible ways of achieving this aim: one is for a country to reinvent its legal systems and the other is for a country to introduce new corporate governance practices into existing corporate governance systems. The paper argues that because of the peculiarity of the Nigerian situation, a combination of both approaches would be needed. The paper concludes that shareholders of Nigerian firms have the potential to positively influence corporate behaviour only if they are able to exercise meaningful control over management.

\section{Shareholding practice and structure in Nigeria: overview and challenges}

The Nigerian Stock Exchange (NSE) has been in existence for about 46 years. According to the NSE, it has over 260 listed securities including 10 Government Stock, 55 industrial loans (Debenture/Preferences) stocks and 
195 equity/ordinary shares of companies with a total capitalization of about 875.2 billion naira. ${ }^{3}$ Shareholding in Nigeria has grown from a few thousands in the early 70 s to an estimated 10 million. The privatization programme in Nigeria has had tremendous impact on share ownership. According to Tanko II, (2004) in the first phase of the programme, privatized companies offered over 1.3 billion shares for sale to the public. Over 800,000 shareholders, many of them first time buyers, purchased the shares. Between 1989 and 2005, forty government-owned companies were privatized.

The early companies in Nigeria were British based. By virtue of Colonial statutes enacted between 1876 and 1922, the law applicable to companies in Nigeria at this time was the 'common law, the doctrines of equity, and the statutes of general application in England on the first day of January, 1900' subject to any later relevant statute. The implication of this approach was that the common law concepts such as the concept of the separate and independent legal personality of companies as enunciated in Salomon $v$. Salomon was received into the Nigeria Company law and has since remained part of the law (Orojo, 1992:17). However with continued growth of trade, the colonialist felt it was necessary to promulgate laws to facilitate business activities locally. The first company law in Nigeria was the Companies Ordinance of 1912, which was a local enactment of the Companies (Consolidation) Act 1908 of England; and even the current company law of Nigeria (now known as the Companies and Allied Matters Act 1990 - CAMA) is largely modelled on the U.K Company Act, 1948 (Guobadia, 2000).

\footnotetext{
${ }^{3}$ NSE information till 2003; see website
} 
Under the Companies and Allied Matters Act (CAMA) (the principal legislation on company law in Nigeria) there are three organs of the company the general meeting, the board of directors and the managing director (to the extent that the board of directors delegate their power to the office) ${ }^{4}$ The two principal organs are the board of directors and the general meeting. The general meeting is the shareholders acting in properly convened meetings. The powers of the two principal organs are set out in the articles of association of a company. ${ }^{5}$ The board of directors are given the exclusive powers to manage a company in accordance with the provisions of the Articles of Association of the company and are not bound to obey the directives of the general meeting (shareholders) when acting in accordance with powers conferred by the articles of association and CAMA. However there are powers conferred on the shareholders under CAMA, which makes them, theoretically, potential effective force in corporate governance. These include default powers to act in any matter if the members of the board of directors are unable to act (because of a deadlock et cetera) or are disqualified from acting in that respect; instituting legal proceeding in the name of or on behalf of the company, where the board of directors refuse or neglect to do so; they also have power to ratify or confirm actions taken by directors and to make recommendations to the board of directors regarding actions to be taken by the board of directors. Furthermore the shareholders acting in the general meeting have the power over the appointment and removal of directors and also to amend the articles of association to alter the powers of directors.

\footnotetext{
4 S. 64 CAMA

5 S 63 (2) CAMA
} 
There are usually two types of meetings under CAMA, the annual general meeting and the extraordinary general meeting. Every company is expected to hold an Annual General Meeting (AGM) every year. Any member or members holding not less than one-tenth of the shares of the company at the date the requisition is made may request for the holding of an extraordinary meeting. The Annual General Meeting is the strongest forum for exerting shareholders influence in the Nigerian Corporate Governance schema. There are usually many important issues of corporate governance, which need the assent of the shareholders at such meetings. For instance, the directors are required to prepare and place before the shareholders at the AGM the financial statement prepared in accordance with CAMA. The shareholders must have the statements delivered to them at least 21 days before the AGM. The shareholders have the prerogative to either approve or reject the statement. Secondly, the AGM has the power to appoint and remove auditors of the company. An auditor is required to report to the shareholders on all the account records and financial statements of the company. An audit committee comprising of equal number of directors and representatives of shareholders is required to examine the auditors report and make recommendation to the AGM.

To facilitate adequate participation of shareholders, it is required under the law that a minimum notice of 21 days must be given to all persons entitled to receive notice of the general meeting. A notice is however, deemed to be properly given if properly addressed and posted. It is required that every 
public company advertises the notice in at least two daily newspapers 21 days before the meeting. However, given the weakness of the Nigerian postal system and the low readership of newspapers in Nigeria the possibility of not receiving adequate notice is high.

Effective exercise of shareholder's powers requires that as many shareholders as possible participate in the voting process. ${ }^{6}$ Only shareholders are entitled to vote on resolutions at general meetings. Where voting is done by a show of hands every member or proxy has one vote. Where voting is done by a poll, a member's voting power will depend on his or her shareholding. A member is entitled to appoint another person including a person who is not a member to attend, vote and speak on his behalf. However, the usual practice in Nigeria is that directors send out proxy papers by which they expressly put themselves forward to be nominated as proxies. This practice according to Orojo (1992:290) inevitably strengthens the position of the directors at general meetings where a sizeable number of proxy papers are returned.

The CAMA allows a shareholder or group of shareholders to propose a resolution or make a statement for the consideration of a general meeting. The shareholder(s) making such a proposal must be member(s) representing not less than one twentieth, i.e. $5 \%$ of the total voting rights of all the members having at the date of the proposal a right to vote at the meeting or by one hundred or more members holding shares in the company which has been

\footnotetext{
${ }^{6}$ European Commission 'Fostering an Appropriate Regime for Shareholders' Rights: Second Consultation by the Services of the Internal Market Directorate General' MARKT/13.05.2005
} 
paid up to an average sum of N500 (i.e. £2) per member. Thus shareholders may influence the direction a company takes via the use of shareholders' resolution. However it has been observed that 'most Annual General Meetings in Nigeria are fraught with corruption. They are arranged in such a way that once the leaders of the shareholders association are bribed in one way or the other shareholders only go to the event to sing the praises of management for a robust account, instead of actually asking accountants to look more closely into the accounts and raising pertinent questions (Gabriel, 2006).

The law makes some provisions for access to the court for redress for minority shareholders. This covers actions brought by an aggrieved shareholder for wrongs done to him personally or to take a derivative action in the name of the company. Furthermore sections $310-312$ of the CAMA allows a shareholder to bring an action on the ground of unfairly prejudicial and oppressive conduct with the court having a wide range of relief to chose from. However, despite the legal provisions, there are many obstacles, which have discouraged a coordinated shareholder activism in Nigeria. There are practical problems such as inadequacy of notices of statutory meetings, inaccessible venue of meetings and inappropriate conducts of meetings. Other problems include lack of information, apathy on the path of shareholders and a weak judicial system.

According to Nmehielle and Nwachue (2004), Nigeria is not characterised by one typology of company. Based on an historical analysis of shareholding structure in Nigeria, they concluded that shareholding in Nigeria is generally 
diffused with few exceptions to the general rule leading to the classic Berle and Means (1932) model on the separation of ownership from control.

Nmehielle and Nwachue traced the diffusion of shareholding back to the indigenisation programme of the government in the 70's. Under the programme, Nigerians bought into companies erstwhile owned by foreigners. However while the Nigerian shareholding was fragmented, the foreign shareholding was intact, making foreign shareholders dominant partners. In this regard, although local shareholders in many instances might be owners of a company because of cumulative larger shareholding, foreigners remained in control, especially because of the weighted voting share scheme which gave more votes to foreign shareholders. This shareholding structure persisted even after the indigenisation scheme and the weighted voting scheme were abolished. Nmehielle and Nwachue further pointed out that by the listing requirement of the Nigerian Stock Exchange, public companies on the First Tier Securities Market are required to have at least 300 shareholders while those on the Second Tier Securities Market are required to have at least 150 shareholders thus further fragmenting the shareholding structure in Nigeria. ${ }^{7}$

The privatisation and commercialisation programme in Nigeria to some extent also contributed to the fragmented share ownership in Nigeria as the enabling statute prohibited the acquisition of more than $0.1 \%$ especially where the shares are oversubscribed. ${ }^{8}$ The exceptions to this general trend are private firms and foreign and local institutional shareholding (which are few) (Limbs

\footnotetext{
${ }^{7}$ Under the listing rules of the Nigerian Stock Exchange, the securities market is divided into tiers depending on the companies' capacity. See Nigerian Stock Exchange Fact Book, 2003.

${ }^{8}$ Section 5(4) of the Privatisation and Commercialisation Act, 1999
} 
and Fort, 2000; Oyejide and Soyibo, 2001). Furthermore, as Nmehielle and Nwachue (2004) pointed out, the shift by the body charged with the privatisation programme in Nigeria which actively sought core strategic investors holding $51 \%$ or more shares in some privatised companies has led to dominant shareholding in such firms. In a similar trend, Tanko (2004) observed that Nigerian investors are so dispersed and the individual holdings generally small that they have no means of exerting any influence on the management of companies post privatisation. According to Maassen and Brown (2006), 'with widely dispersed share ownership, minimum standards for formal communication and disclosure must be regulated through corporate law and self-regulation such as voluntary corporate governance codes'. They importantly noted that 'such communication, disclosure, and governance mechanisms will be of value only if the shareholders are empowered to act on such information.'

According to a survey by Oyejide and Soyibo (2001) Nigeria score poorly on fair conduct of shareholders' meetings when compared to other emerging markets in the Middle East and North Africa. The survey covered important issues impacting on shareholders right such as the handling of general meetings, prohibition of insider dealings, publication of director dealings and transactions, adequate notification to shareholders, transparency, judicial remedies and access to information. The survey reveals that all shareholders do not have equal access to information. In fact $95 \%$ of the respondents to the survey were of the opinion that there was no meaningful compliance to this requirement and that compliance and enforcement is inconsistent. As regards 
shareholders access to judicial remedies, $70 \%$ of respondents feel that there is no evidence of any legal/administrative system with respect to shareholders rights while $25 \%$ was of the opinion that the system does not work. $75 \%$ of the respondents were of the opinion that there was inconsistent quality of information during company meetings in Nigeria. While insider trading is effectively prohibited in Nigeria the survey shows compliance/enforcement is inconsistent in the country. The recent case of Cadbury Nigeria Plc (see appendix) is an eloquent testimony to the shareholding challenges in Nigeria.

\section{Recent changes and developments towards shareholders empowerment, activism and strategic corporate governance in Nigeria}

According to Aguilera and Cuervo-Cazurra (2004) the processes of globalization - such as the liberalization and internationalization of economies, developments in telecommunications, and the integration of capital markets - and the transformation in the ownership structure of firms due to the growth of institutional investors, privatization and rising shareholder activism - have led to increased attention been paid to corporate governance as a monitoring and accountability device. These processes have also impacted on the Nigerian environment with the ongoing privatisation and commercialization programme, the liberalization of the regulatory framework for investment and the transformation in the communication sector. Some of these changes have important bearing on shareholder activism within the local context. 
Some of the recent reforms towards shareholder empowerment in Nigeria include: a new code of corporate governance, formation of shareholder associations and the emergence of information and communication technologies. Each of these changes and developments would be related to the galvanisation of shareholder activism in Nigeria.

\section{The Code of Corporate Governance}

Following poor shareholding practices and further marginalization of shareholders in corporate democracy in Nigeria, a code of Corporate Governance was adopted in 2003 by the Nigerian Securities and Exchange Commission and the Corporate Affairs Commission which made a number of recommendations to increase the level of shareholders influence in corporate decision making process. Code of corporate governance has been recognised as 'a set of 'best practice' recommendations regarding the behaviour and structure of a firms board of directors issued to compensate for deficiencies in a country's corporate governance system regarding the protection of shareholders' rights' (Aguilera and Cuervo -Cazurra, 2004). The Nigerian code thus focuses on shareholders unlike similar codes in other African countries, which extended their scope to a broader range of stakeholders (Rossouw, 2005). A major recommendation of the code is that shareholders should work in concert through shareholders associations.

Section 10 (a) of the code provides: 
'The company or the board should not discourage shareholder activism whether by institutional shareholders or by organized shareholders' groups. Shareholders with larger holdings (institutional and non-institutional) should act and influence the standard of corporate governance positively and thereby optimize stakeholder value.'

Regarding the composition of Board of Directors, the code provides that shareholders with less than $20 \%$ or more shareholding should have a seat on the board. It further provides that a Director representing the interest of minority shareholders should be given a seat on the board. The code further provides for more regular briefings of shareholders going beyond going beyond the half year and yearly reports.

To facilitate and improve the attendance of shareholders at general meetings of the company, the code states that venue for general meetings should be places that are possible and affordable - cost and distance wise - for a majority of shareholders to attend and vote at annual general meetings. The code further requires that notice of meeting be given at least 21 days before the meeting and all details related to the agenda of a meeting should accompany the notice to enable shareholders properly exercise their vote. The code envisages that the general meeting should be a forum for shareholder participation in the governance of the company. The changes in code of corporate governance have contributed to strengthening of 
shareholders in Nigeria and have begun to yield some fruits (e.g. Cadbury Plc case).

\section{Shareholders' Association}

The trend in developed economies, which saw the development of block voting through shareholder associations as a response to domination by principal shareholders, ${ }^{9}$ is gradually evolving in the Nigerian context. The bonding together of shareholders in Nigeria has come both through private initiatives and government intervention. In a bid to shore up public participation in the ownership of corporation the Nigerian government encouraged and facilitated the establishment of a network of Shareholder Associations. Seven Zonal associations were established in 1992. The country was divided into seven zones and zonal headquarters were located in seven major cities, which are Kano, Kaduna, Jos, Ibadan, Lagos, Onitsha and Port Harcourt, respectively. Each of the Zonal Associations is registered with the Corporate Affairs Commission; the government department charged with the regulation of formation and management of companies the country. ${ }^{10}$ The associations adopted a draft constitution provided by a government department, the Bureau of Public Enterprises. The Government also ensures that publicly quoted companies allocate seats to the associations on the board of corporations. Each of the zones has a board of Trustees, which is elected to hold office for life. There is also provision for an executive council charged

\footnotetext{
${ }_{9}^{\prime}$ 'Improving the Exercise of Shareholder Voting Rights at General Meetings in France' Report of Working Group of the Authourite des Marches Financiers (AMF) - France Securities Regulator chaired by Yves Mansion, September, 2005

${ }^{10}$ It also registers Business Names and Incorporated Trustees as well as providing a wide range of ancillary services. The associations operate independently of each other.
} 
principally with coordinating the affairs of the association, electing members of their zone to fill in any board vacancies by shareholders of the company involved, educating shareholders in their zones. Each zone keeps a register of shareholders in the privatised publicly quoted companies. According to Etukudo (2000) 'the Association serves the interest of the investing public as shareholders who have the opportunity to contribute to the formulation of broad corporate policies, thereby enhancing management accountability'.

At its inception a government parastatal in charge of the privatisation and commercialisation programme, the Bureau of Public Enterprises (BPE), funded the association from interest earned on deposit of shares pending allotment. The association is now funded through a per-capital levy placed on quoted companies. The Securities and Exchange Commission and the Nigerian Stock Exchange determine the levy, based on the number of shareholders in each company. The fund is collected and administered by the Stock Exchange.

Though the association obtains professional guidance from the Nigerian Stock Exchange, its activities are determined and solely carried out by its members in accordance with its constitution. The purpose of the Associations, as conceived by the government, is to ensure that Nigerians have representation and a voice in the running of the affairs of firms in which they invest. The duties of the association according to Etukudo (2000) include: 
'-- educating and enlightening shareholders on their rights and responsibilities;

-- promoting solidarity among shareholders and stimulating interest in the activities of their company;

-- facilitating representative participation in corporate decision-making through regular attendance at annual general meetings as well as extra-ordinary general meetings;

-- nominating their representatives to serve on boards of directors of publicly quoted companies;

-- facilitating easy access to individuals to claim their dividends and scrip certificates some of which remain unclaimed due to ignorance of their whereabouts. '

Apart from the government established shareholder associations, there are also independent associations of shareholders in Nigeria. These are usually regarded as activist associations put together for common causes, by individuals with common interests. The emergence of this private shareholder associations shows that Nigerian investors are no longer solely interested in the economic value of their shares but also in the right that share ownership gives them to influence corporate strategy and management. ${ }^{11}$ In the last 15 years at least 30 shareholders association have been established. ${ }^{12}$ The increasing number of these associations has led to recent moves by the

\footnotetext{
11 Some of the major private Shareholder Association in Nigeria include ' Independent Shareholders Association of Nigeria, Shareholders Solidarity Association of Nigeria, Nigeria Shareholders Solidarity Association, Nigeria Professional Shareholders Association, the Independent Shareholders Association, and the Association for the Advancement of Rights of Shareholders.

12 Sola Ephraim-Oluwanuga 'Role of Shareholders in Implementing the Code of Corporate Governance' available at http://www.businessdayonline.com
} 
Securities and Exchange Commission in Nigeria to regulate the associations. $^{13}$

Okike (2007) has opined that the emergence of these associations have led to a rise in shareholder activism in Nigeria. According to her, after analysing recent newspaper reports on shareholder associations in the country,

Contrary to the belief that shareholders in Nigeria are ignorant and naive, the evidence of actions by the NSSA and other shareholder bodies points to the fact that such assumption is antiquated. In Nigeria shareholders have been known to challenge the actions of management they believe were not taken in their best interest...'

It has been reported that shareholder associations have contrary to previous practice, rejected yearly account of some companies, opposed appointment of certain directors and went to court to some proposed mergers (Okike, 2007). A good example of this is the current case between Cadbury and local shareholders in Nigeria. ${ }^{14}$ It is thus obvious that if properly channelled, shareholder activism is a potential force for shaping the direction corporate decision making takes in the country.

\footnotetext{
${ }^{13}$ See Business Day, June 22nd, 2006 - 'SEC may review Audit Committee Membership'. However it should be noted that in the developed economies block voting through associations have transcended the exclusive preserves of volunteers because of the emergence of service firms called 'proxy providers', which provides institutional investors and companies with large scale voting services. See 'Improving the Exercise of Shareholder Voting Rights at General Meetings in France' Report of Working Group of the Authourite des Marches Financiers (AMF) - France Securities Regulator chaired by Yves Mansion, September, 2005

14 See Tosin Sulaiman 'Cadbury Nigeria sued by Investors over Accounting' The Times (March 12, 2007) available at http://business.timesonline.co.uk/tol/business/industry sectors/consumer goods/article1499780.ece accessed 02/05/07
} 
The role of the Internet and the Global System of Mobile Communication on Shareholder activities

In addition to the changes in code of corporate governance and formation of shareholders associations, two important technological developments have helped the bonding together of shareholders for common purposes in Nigeria. The growth of the Global System of mobile Communication and the use of the Internet has made communication easier and information accessible. Though subscription to the Internet is low, but its availability and the availability of Internet cafes in all major towns in the country have increased access to information. Investors / shareholders now find it easier to access information about companies and also to share information with other investors unlike before. Majority of companies listed on the Nigerian Stock Exchange now have websites and use these to present their annual reports and other activities that might be of interest to shareholders.

In addition to company websites, it is now possible to find websites where discussions are held on what investments to put money on. ${ }^{15}$ Furthermore the Global System of Communication makes it easier for shareholders to share views and discuss issues. In other words, the internet technology and

\footnotetext{
${ }^{15}$ Examples of website where discussions are held include Nairaland http://www.nairaland.com/nigeria owned by a young Nigerian based in Ogun State, Nigeria. Also The Nigeria Village Square - www.nigeriavillagesquare.com
} 
economy has contributed to empowering shareholders in Nigeria and made management much more susceptible to accountability pressures.

Increasing Shareholders participation in Nigeria: any lessons from abroad?

Despite the improvements from reformed code of corporate governance, formation of shareholders' associations and developments in information technology, there are still room for improvements. Undoubtedly the Annual General Meeting (AGM) is the most viable avenue for shareholders to exert their influence. It is therefore important to find ways of increasing shareholders participation in AGM. The recent developments regarding shareholder associations demonstrates the fact that given the right atmosphere, shareholders in Nigeria would likely take active interest in the governance of corporations.

Even though the European Union is much more advanced in this area (like in many other areas) than Nigeria, there are instructive lessons in developments in the EU, which could be adapted suitably to the Nigerian scenario. While the current challenges to shareholders democracy in the EU differ considerably from Nigeria and are largely linked to cross border equity investments, the steps that have been taken to ameliorate the situation are instructive. This is relevant because the steps taken in the EU context were also to increase shareholders participation in corporate governance. Under the EU 2004 Transparency Directive, timely disclosure of information including 
place, time and agenda of meetings are required. The directive enables the usage of electronic means to pass information to shareholders (Maasen and Brown, 2006). Furthermore the Market Abuse Directive in its effect requires that companies have Internet sites to which they must post all information that they are required to disclose publicly.

There are many advantages to employing modern technologies in this regard. It has been observed that in the US where there is a more common use of proxy solicitation through Internet and phones, cost is saved at the same time a greater quorum is achieved. This is achieved by outsourcing the proxy process. According to Maasen and Brown (2006), ADP the largest proxy processing company in the US processed more than 153 million proxy pieces covering more than 299 billion shares in 2005 . A total of 168.2 billion votes were cast electronically by phone Internet and Proxy Edge in the year. The cost of reaching out to shareholders was reduced by this method by more than $\$ 370$ million in 2005 due to savings on postage and paper.

In Nigeria the increase in the use of the Internet and the GSM system could provide an avenue for increasing shareholder participation. For examples by dedicating a part of companies website to shareholder information, by ensuring that shareholders can additionally be contacted through emails and the global System for Mobile Communication and by facilitating the processing of shareholder's questions through these media. Furthermore, in view of the epileptic service provided by the postal system in Nigeria and the limitation attached to most system of communication in Nigeria due to poor 
infrastructure it is recommended that the length of notice of meeting be increased from 21 days to sixty day and should be published on the website at the same time. It is interesting to note that in Europe where there is adequate infrastructure there is a pending proposal that notice of general meetings should be a minimum of 30 calendar days and should be posted on the Internet at the same time as it is published (Maasen and Brown, 2006).

The EU has proposed that shareholders in the cross border context should have the right to ask questions at least in writing ahead of general meetings and get responses to their questions. The responses, it is proposed, should be made available to all shareholders. This also could be adapted to the Nigerian situation by allowing questions to be asked through the post and the internet ahead of general meetings.

\section{Conclusion and implications for corporate social responsibility in}

\section{Nigeria}

This paper has examined opportunities for shareholder activism within the Nigerian corporate governance schema in the light of recent developments. Shareholder dominant theories - contract and agency theories - are of the view that because of the wide dispersal of shareholding, direct shareholders control is hampered, consequently putting into question shareholder democracy and activism. Berle and Means (1932) seminal work The Modern Corporation and Private Property brought to the fore what has been subject of considerable debate in corporate governance for decades thereafter: the 
separation of ownership from control. Simply put, 'shareholders own an entity that management runs' (Marcus, 2003). However, Berle and Means qualified the 'ownership' status of shareholders as passive owners who had surrendered control to management. As Fannon (2003) further expounded, the documented attitude of shareholders is to exit when there is dissatisfaction with corporations' performance rather than attempting to exert influence, as true owners of property would do to rectify any shortcoming - a phenomenon commonly refer to as rational neutrality or indifference. The consequence of this is that share price becomes the sole indicator of shareholders view in the corporate structure. It is thus assumed that the option for any dissatisfied shareholders is to sell and leave the corporation.

However, the political model of corporate governance as it interacts with the theory of power and cybernetic analysis provides a different perspective (Turnbull, 1997). The political model of corporate governance at the micro level of the firm has been described as an approach 'in which active investors seek to change corporate policy by developing voting support from dispersed shareholders, rather than by simply purchasing voting power or control...' (Pound, 1993). This model of governance is based on politics rather finance (Pounds, 1993) and recognizes the existence of political market place apart from government establishments. According to Turnbull (1993), possession of power to act where the knowledge and will to act is present, is an integral part of political model of corporate governance. Power relation among stakeholders is important because even where there is greater disclosure and transparency shareholders must possess both the power and the will to act. 
This echoes the Focauldian conception of power as power only when it is exercised (Kearins, 1996). However power would only be rightly exercised where the relevant stakeholder is in possession of accurate information that is timely, sufficient and manageable (Turnbull, 1997)

The political model of corporate governance as described above would explain the emergence of shareholder activism in its various manifestations in recent times. According to O'Rourke (2003),

'Shareholder groups are increasingly going beyond the decision to invest, not to invest, or to divest by proposing and voting on company specific corporate social responsibility (CSR) issues at annual shareholder meetings. This activity is joined by an increasing sophisticated 'strategy of engagement' by both shareholders and companies. In the process, a model of investor capitalism based on 'responsible ownership' is being forged that addresses social and environmental issues previously outside the domain of most shareholders'.

The connection between shareholder activism and corporate social responsibility is under-emphasised in CSR discourses. Instead, shareholders are often presented as 'ruthless capitalists' who are only driven by profit maximisation. However, the emergent and growing interest in social responsible investments $(\mathrm{SRI})$ seems to contrast sharply with what has 
become a conventional misrepresentation of shareholders' interest in the extant CSR literature.

In a recent paper on CSR in Nigeria, Amaeshi et al. (2006) found that CSR in Nigeria is dominantly understood and practised as corporate philanthropy, which is most of the time driven by the whims and caprices of management. In this regard, there is a high risk of management pursuing their interests and not necessarily those of shareholders (i.e. investors) - thereby feathering own nests, reputations and personal aspirations, instead, at the expense of shareholders wealth. In addition, Amaeshi et al. concluded that the attraction towards corporate philanthropy is driven by the corporate governance framework in which these firms are embedded. Whilst not being critical of this cultural and institutional bias, this paper argues that there are opportunities in the ongoing corporate governance reforms in Nigeria that would give individual shareholders voice in moving the firms they invest in beyond corporate philanthropy to meeting their strategic objectives and adding real value to the Nigerian economy. For instance, shareholders ability to hold management to account would encourage management to be more strategic in their approach to CSR instead of relying on personal interests and aspirations expressed through corporate philanthropy. It is the conclusion of this paper that shareholder empowerment in corporate decision making is a potential avenue for influencing corporate attitude towards CSR as evidence from the US and EU has demonstrated. 


\section{References}

Aguilera, R.V., and Cuervo-Cazurra A. (2004) Codes of Good Governance Worldwide: What is the Trigger? Organization Studies 25: 415 Aguilera, R.V., and Jackson G. (2003) The Cross-National Diversity of Corporate Governance: Dimensions and Determinants' Academy of Management Review 28(3): 447-465

Ahunwan, B. (2002) 'Corporate Governance in Nigeria', Journal of Business Ethics 37: 269-87.

Ahunwan, B. (2002). Corporate Governance in Nigeria. Journal of Business Ethics 37:269

Amaeshi, K. M., Adi, B. C., Ogbechie, C., and Amao, O. O. (2006). Corporate Social Responsibility in Nigeria: Western Mimicry or Indigenous Influences? Journal of Corporate Citizenship, 24 (winter) 83-99

Berle A.A., and Means C.G.,(1932) The Modern Corporation and Private Property (New York: Commerce Clearing House)

Ephraim-Oluwanuga, S. (2007) 'Role of Shareholders in Implementing the Code of Corporate Governance' available at http://www.businessdayonline.com

Etukudo, A. (2000) Issues In Privatization And Restructuring In Sub-Saharan Africa - Interdepartmental Action Programme on Privatization, Restructuring and Economic Democracy Working Paper IPPRED-5 http://www.ilo.org/public/english/employment/ent/papers/ippred5.htm 
European Commission 'Fostering an Appropriate Regime for Shareholders' Rights: Second Consultation by the Services of the Internal Market Directorate General' MARKT/13.05.2005

Fannon, L.I. (2003) Working within Two Kinds of Capitalism: Corporate Governance and Employee Stakeholding: US and EU Perspectives (Oxford-Portland: Hart Publishing).

Gabriel, O. (2006) 'Bunmi Oni caught in Financial Numbers Game, how many more are out there (1)' Vanguard Newspapers, December 18, 2006

Kearins, K. (1996). 'Power in Organizational Analysis: Delineating and Contrasting a Foucauldian Perspective' Electronic Journal of Radical Organizational Theory Vol. 2 No 2 (September 1996) available at http://www.mngt.waikato.ac.nz/ejrot/EJROT(newdesign)Vol2 2 front.as $\underline{p}$

Limbs, E. C. and Fort, T. (2000). 'Nigerian Business Practices and Their Interface with Virtue Ethics, Journal of Business Ethics 26: 169 -179

Maasen, G. F. and Brown, D. (2006). 'The Effectiveness of Shareholders' Meetings: An Overview of Recent Developments' in Paul U. Ali and Greg N. Gregoriou International Corporate Governance after SarbanesOxley' Wiley, New Jersey, 2006 p.223 - 265

Marcus, D. (2003) 'Walking and Talking, Daily Deal, 7 November, 2003

McNeil, G. I. (2005). An Introduction to the Law on Financial Investments. Hart Publishing, Oxford, p252, 256

O' Rourke, A. (2003). 'A New Politics of Engagement: Shareholder Activism for Corporate Social Responsibility' Business Strategy and Environment $12: 227-239$ 
Okike, E. N. M. (2007). 'Corporate Governance in Nigeria: the status quo' Corporate Governance: An International Review, 15(2):173-193

Oyejide, T. A. and Soyibo, A. (2001). Corporate Governance in Nigeria. Paper Presented at the Conference on Corporate Governance, Accra, Ghana, 29 - 30 January, 2001.

Pound, J. (1993). 'The Rise of the Political Model of Corporate Governance and Corporate Control, New York University Law Review, 6(5), 1005 , 1993

Rossouw, G. J. (2005). 'Business Ethics and Corporate Governance in Africa' Business and Society, Vol.44 No.1, March 2005, 94-106 (p.97)

Tanko II, M. (2004). The impact of privitization on Capital Market Development and Individual Share Ownership (October, 3 2004) - Available at http://papers.ssrn.com/sol3/papers.cfm?abstract id=689702 accessed $21 / 04 / 07$

Turnbull, S. (1997). Corporate Governance: Its scope, concerns \& theories' Corporate Governance: An International Review, I.5(4):180 -205 


\section{Appendix}

\section{Cadbury Nigeria PIc: An Example of Shareholder's Failure?}

International interests have been attracted to Nigeria recently due to the discovery of Enron like Scandal in the subsidiary of Cadbury Schweppes in Nigeria: Cadbury Nigeria Plc. Concerns have been raised particularly because of the company's high profile in the private sector and domestic economy and as a major player on the Nigerian Stock exchange. The fact that it took Cadbury Schweppes, the parent company's intervention to discover the irregularities have called into question the capacity of the Nigerian corporate governance environment and framework. It must be observed that the financial accounts in question were scrutinized and approved by the Nigerian Stock Exchange, the Security Exchange Commission and most importantly in this connection the shareholders of the company.

Cadbury Nigerian Plc has been listed on the Nigerian Stock Exchange since 1976, and is in the top 10 of the 258 quoted equities by market capitalizations as of year end 2003. Cadbury Schweppes until very recently owned $46.3 \%$ of the equity of the company with the balance stock held by approximately 51,000 individual and institutional shareholders. ${ }^{16}$ The company employ more than 2000 employees and its sales turnover in 2003 was around US $\$ 150$ Million.

\footnotetext{
${ }^{16}$ http://cadburynigeria.com/news.php
} 
On the 12th of December, 2006 the company released a statement stating inter alia

'We are now able to inform all stakeholders of Cadbury Nigeria Plc that the independent investigator of our financial statements, PricewaterhouseCoopers, has submitted a report of their findings. The investigation has confirmed a significant and deliberate overstatement of the company's financial position over a number of years.

On account of this, Cadbury Nigeria Plc will report an underlying operating loss for 2006 of between $\mathrm{N} 1$ and 2 billion. We also expected to make one- time exceptional charges in 2006 of between N13 billion and N15 billion in respects of the profit and balance sheet overstatements, which will considerably diminish company reserves.'

Following this incident, the managing director and chief executive officer of the company and the financial director were removed and a complete review of the company's business model was ordered. ${ }^{17}$

In this connection, investors, including pension fund managers, have since the revelation lost a lot of money. Since the exposure of the company's misrepresentation of their financial statements, the shares of the company declined from its high of N70 on the 18 of August, 2006 to N32.46 - a 
reduction of $46 \%$ - on December, 2006 translating into a loss estimated to be in the region of $\mathrm{N} 41.3$ billion in shareholders equity.

The state of affair in Nigeria, a country which is striving to gain the confidence of investors both foreign and local is further undermining investor's confidence in the economy. The shareholders are not the only persons who stand to lose in this scenario as such developments could lead to job losses in an economy dogged by chronic unemployment. 